\title{
KONDISI SOSIAL EKONOMI DAN KESEHATAN MASYARAKAT KAMPUNG PUNAN MALINAU KABUPATEN BERAU DENGAN KEBERADAAN BEBERAPA PERUSAHAAN SAWIT
}

\section{SOCIAL ECONOMIC AND COMMUNITY HEALTH CONDITIONS OF PUNAN MALINAU VILLAGE BERAU DISTRICT WITH THE EXISTENCE OF SOME PALM COMPANIES}

\author{
Sri Ngapiyatun ${ }^{\text {* }}$, Sri Hartini', Humairo Aziza1, Wartomo1, Sukariyan', \\ Rossy Mirasari ${ }^{1}$ dan Rusli Anwar ${ }^{1}$ \\ ${ }^{1}$ Politeknik Pertanian Negeri Samarinda, JI. Samratulangi PO BOX 192 Samarinda \\ *ngapiyatun.77@gmail.com
}

\begin{abstract}
This research background with a lot of oil companies that thrive in Kampung Punan Malinau it could be an impact on changes in socioeconomic conditions and public health, for the study aims to determine the interaction social, education, income, accessibility, and health.

Based on the results of this study it can be concluded that the work of the people of Punan Malinau Village who used to be farming, now there is progress working in oil palm companies in the Punan Malinau Village area. The presence of companies economically also has a positive impact on the development of alternative sources of livelihood, namely the recruitment of local workers in companies and access to marketing of agricultural products that are well developed.

Meanwhile, in terms of public income before the company existed it was only under Rp. 1,000,000, - but after the existence of the oil palm company, the income has increased, namely Rp. 4,000,000 to Rp. 5,000,000 and more are supported by their personal income, namely private oil palm plantations that can reach $R p .16,000,000$ and more per month.
\end{abstract}

Keywords: Kampung Punan Malinau, Public health, Oil Plantation, Socioeconomic

\section{PENDAHULUAN}

Era pengembangan kelapa sawit di Kalimantan Timur dimulai pada tahun 1982 yang dirintis melalui Proyek Perkebunan Init Rakyat (PIR) yang dikelola oleh PTP VI. Perkebunan kelapa sawit jadi primadona seiring manfaat positif pertumbuhan ekonomi yang dirasakan masyarakat. Gubernur Kaltim Awang Faroek Ishak yang memimpikan Kaltim mampu melakukan upaya untuk kemandirian dan ketahanan pangan. Imbasnya pada kesejahteraan rakyat, sebagai buah jerih payah dan kesungguhan menggapai mimpi. Yaitu "Dreams come true" program 1 juta hektar kelapa sawit jadi kenyataan. Bahkan waktunya lebih cepat tercapai dari yang telah diprediksi.

Hingga tahun 2019 luas areal kelapa sawit mencapai 1.228 .138 ha yang terdiri dari 255.919 ha milik BUMN sebagai tanaman plasma/rakyat, 14.402 ha milik BUMN sebagai inti dan 957.817 ha milik Perkebunan Besar Swasta. Produksi TBS (Tandan Buah Segar) yang diolah pada tahun 2018 sebesar 18.343.852 ton atau setara dengan 4.048.064 ton Crude Palm Oil (CPO). Dari sejumlah perusahaan perkebunan besar swasta yang telah memperoleh izin pencadangan (ijin lokasi) sementara ini yang telah beroperasi membangun kebun dalam skala yang luas baru sebanyak 393 (Sumber: disbun.kaltimprov.go.id).

Dampak perkebunan kelapa sawit wilayah Kampung Punan Malinau membawa dampak positif dan negatif. Dampak positif adalah mengurangi pengangguran masyarakat kampung, menciptakan lapangan kerja baru, menambah pendapatan rumah tangga serta menambah pengetahuan tentang budidaya kelapa sawit, sedangkan dampak negatif yang dirasakan merugikan masyarakat diantaranya adalah lahan yang diolah untuk usaha 
taninya berkurang, adanya pencemaran dan pendangkalan anak sungai dari aktivitas kebun kelapa sawit.

$$
\text { Kampung Punan Malinau }
$$

merupakan salah satu Kampung di Kecamatan Segah yang berada diantara usaha perkebunan kelapa sawit milik PT. Malindomas Perkebunan, PT. Natura Pasifik Nusantara dan PT. Berau Karetindo Lestari. Kampung Punan Malinau merupakan wilayah Kecamatan Segah yang menjadikan wilayah kampung ini menjadi sangat strategis dikarenakan selain berbatasan langsung dengan kecamatan, kampung ini juga berbatasan langsung dengan kawasan industri di Provinsi Kalimantan Timur.

Rumusan masalah pada penelitian ini adalah bagaimana kondisi sosial ekonomi dan kesehatan masyarakat lokal sebelum dan sesudah berdirinya perusahaan kelapa sawit di Kampung Punan Malinau, Kecamatan Segah, Kabupaten Berau, Provinsi Kalimantan Timur

Penelitian ini bertujuan mengetahui kondisi sosial ekonomi dan kesehatan masyarakat lokal di Kampung Punan Malinau yaitu interaksi sosial, pendidikan, pekerjaan, pendapatan, aksesibilitas dan kesehatan.

Hasil yang diharapkan dari penelitian ini menjadi masukan bagi masyarakat Kampung Punan Malinau dan pihak perusahaan agar selalu terjalin hubungan baik.

\section{METODOLOGI}

\section{Lokasi dan Waktu Penelitian}

Penelitian ini dilaksanakan di kampung Punan Malinau, kecamatan Segah, kabupaten Berau, Provinsi Kalimantan Timur selama 1 bulan terhitung mulai tanggal 21 Oktober sampai dengan 21 November 2020, yang meliputi kegiatan survei lokasi, kuesioner dan wawancara.

\section{Alat dan Bahan Penelitian}

Alat dan bahan yang digunakan dalam penelitian ini adalah laptop, alat tulis, kamera handphone, sedangkan bahan yang digunakan kuesioner penelitian.

\section{Prosedur Penelitian \\ 1. Penentuan sampel}

Menetapkan sampling berdasarkan KK yaitu 174 subjek dan diambil 25\%, maka penelitian ini menggunakan $44 \mathrm{KK}$ total sampling. Menurut Arikunto (2010), jika populasi kurang dari 100 lebih baik diambil semua, jika populasi lebih dari 100 dapat diambil $10 \%-15 \%$ atau $20 \%$ $25 \%$ atau lebih.

Menurut Arikunto (2010), ada beberapa teknik pengambilan sampel penelitian, namun yang digunakan dalam penelitian ini adalah teknik sampel random atau sampel acak. Teknik sampel random atau sampel acak adalah peneliti memilih subjek secara acak dan seluruh sampel dianggap sama. Dengan kata lain peneliti memberi hak yang sama terhadap subjek untuk memperoleh kesempatan (chance) dipilih menjadi sampel. Subjek yang dimaksud dalam penelitian ini adalah masyarakat Kampung Punan Malinau.

\section{Pelaksanaan wawancara}

Setelah itu melakukan wawancara pengisian data responden dimana peneliti melakukan wawancara secara langsung mendatangi satu persatu responden, dengan dasar kuesioner, kemudian melakukan pengolahan data dengan penentuan skor dengan cara menghitung hasil kuesioner yang mengacu pada skala likert.

Pertanyaan yang menggunakan skala likert mempunyai gradasi dari yang sangat negatif sampai sangat positif dengan 5 (lima) alternatif jawaban. Dengan menggunakan skala likert masing-masing instrumen jawaban memiliki nilai yaitu Sangat Baik (A:5), baik (B:4), Cukup (C:3), Kurang (D:2) dan Sangat Kurang (E:1).

\section{Analisa data}

Skala Likert menurut Sugiyono (2014) ialah skala likert yang dapat dipergunakan untuk mengukur sikap, 
pendapat, dan persepsi seseorang atau sekelompok orang tentang fenomena sosial dengan Skala Likert. Maka variabel yang akan diukur dijabarkan menjadi indikator variabel. Skala Likert adalah suatu skala psikometrik yang umum digunakan dalam angket, kuesioner dan merupakan skala yang paling banyak digunakan dalam riset berupa survei. Nama skala ini diambil dari nama Renssi Liker, yang menerbitkan suatu laporan.

Analisis data dilakukan secara deskriptif kualitatif. Tujuan dari penelitian ini adalah untuk mengungkapkan kejadian atau fakta, keadaan, fenomena, variabel dan keadaan yang terjadi saat penelitian ini berlangsung dengan menyuguhkan apa yang sebenarnya terjadi. Penelitian ini menafsirkan dan menguraikan data yang bersangkutan dengan situasi yang sedang terjadi, sikap serta pandangan yang terjadi didalam suatu masyarakat. pertentangan antara dua keadaan atau lebih, hubungan antar variabel yang timbul, perbedaan antar fakta yang ada serta pengaruhnya terhadap suatu kondisi, dan sebagainya. Untuk tujuan penelitian ini kondisi sosial ekonomi dan kesehatan masyarakat Kampung Punan Malinau dengan keberadaan beberapa perusahaan sawit di wilayahnya dilakukan dengan analisis kualitatif. Dapat dilihat pada tabel 1.

Tabel 1. Cara Perhitungan Skala Likert

\begin{tabular}{lccccc}
\multicolumn{1}{c}{ Indikator } & $\begin{array}{c}\text { Skor Kuesioner } \\
\text { (SK) }\end{array}$ & $\begin{array}{c}\text { Skor Maksimal } \\
(\mathrm{SM})\end{array}$ & SK/ST*100\% & $\begin{array}{r}\text { Hasil } \\
(\%)\end{array}$ & $\begin{array}{r}\text { Kateg } \\
\text { ori }\end{array}$ \\
\hline Interaksi Sosial & & & & \\
Pendidikan & & & & \\
Pekerjaan & & & & \\
Pendapatan & & & & \\
Aksesbilitas & & & \\
Kesehatan & \multicolumn{1}{c}{ Total } & & & & \\
\hline
\end{tabular}

Sumber. Tabel Skala Likert

Setelah seluruh kuesioner yang didistribusikan terkumpul, maka langkah selanjutnya adalah menghitung rekapitulasi nilai setiap indikator yang didapat dari para masyarakat. Nilai tersebut kemudian dijumlahkan untuk memperoleh total skor dan pencapaian interval. Selanjutnya untuk menentukan kategori kondisi berdasarkan kriteria interprestasi skornya berdasarkan interval standar skor skala likert seperti pada tabel 2.

Tabel 2. Interval Penilaian Skala Likert

\begin{tabular}{cc}
\hline Range Skor $(\%)$ & Kategori \\
\hline $0-19,99$ & Sangat Kurang Baik \\
$20-39,99$ & Kurang Baik \\
$40-59,99$ & Cukup Baik \\
$60-79,99$ & Baik \\
$80-100$ & Sangat Baik \\
\hline
\end{tabular}

HASIL DAN PEMBAHASAN

\section{Hasil}

Hasil penelitian kondisi sosial ekonomi dan kesehatan masyarakat dengan keberadaan beberapa perusahaan sawit yang telah dilakukan perhitungan nilai serta penentuan interval disajikan pada tabel 3 .

\section{Interaksi Sosial}

Indikator dari interaksi sosial yang terdiri dari nilai gotong-royong, meringankan sebuah pekerjaan, saling menegur dan berbincang dengan masyarakat lainnya, musyawarah, toleransi, hubungan baik dengan perusahaan, perusahaan selalu memberikan bantuan pada masyarakat. Interaksi sosial Kampung Punan Malinau skornya adalah 1.396, skor maksimal indikator dari interaksi sosial adalah 1.540. Dengan menentukan nilai interaksi sosial adalah 90,65\%, dan berdasarkan skala likert tergolong sangat baik.

2. Pendidikan 
Indikator dari pendidikan yang terdiri dari nilai pendidikan terakhir, pendidkan anak, tersedia lembaga pendidikan (fasilitas), pendidikan sangat penting, biaya kebutuhan anak terpenuhi. Pendidikan masyarakat Kampung Punan Malinau skornya adalah 1035, skor maksimal indikator pendidikan adalah 1.100. dengan menentukan nilai pendidikan adalah $94,09 \%$, dan berdasarkan skala likert tergolong sangat baik.

\section{Pekerjaan}

Indikator dari pekerjaan yang terdiri dari nilai pekerjaan saat ini, pekerjaan sebelum adanya perusahaan sawit, setelah adanya perusahaan sawit apakah anda bekerja dan apa jabatan anda, penghasilan sesuai dengan pekerjaan, sudah memahami pekerjaan, posisi apa yang anda sangat inginkan disebuah perusahaan.
Pekerjaan masyarakat Kampung Punan Malinau skornya adalah 984, skor maksimal indikator pekerjaan adalah 1.320. Dengan menentukan nilai pekerjaan adalah $74,55 \%$, dan berdasarkan skala likert tergolong baik.

4. Pendapatan

Indikator dari pendapatan yang terdiri dari nilai pendapatan pribadi dalam 1 bulan berkisar, jumlah tabungan saat ini, jenis kendaraan yang dimiliki, sumber pendapatan lain, apakah masyarakat kampung dipersulit saat melamar pekerjaan diperusahaan tersebut. Pendapatan Kampung Punan Malinau skornya adalah 1001, skor maksimal indikator pendapatan adalah 1.100. Dengan menentukan nilai pendapatan adalah $91,00 \%$, dan berdasarkan skala likert tergolong sangat baik.

Tabel 3. Hasil Perhitungan nilai dan penentuan interval kondisi sosial ekonomi dan kesehatan masyarakat Kampung Punan Malinau.

\begin{tabular}{|c|c|c|c|c|}
\hline Indikator & Skor Kuesioner (SK) & Skor Maksimal (SM) & Hasil(\%) & Kategori \\
\hline Intraksi Sosial & 1396 & 1540 & 90,65 & Sangat Baik \\
\hline Pendidikan & 1035 & 1100 & 94,09 & Sangat Baik \\
\hline Pekerjaan & 984 & 1320 & 74,55 & Baik \\
\hline Pendapatan & 1001 & 1100 & 91,00 & Sangat Baik \\
\hline Aksesbilitas & 965 & 1100 & 87,73 & Sangat Baik \\
\hline Kesehatan & 1045 & 1100 & 95,00 & sangat Baik \\
\hline Total & 6426 & 7260 & 88,51 & Sangat Baik \\
\hline
\end{tabular}

Sumber: Data Diolah (Hasil Penelitian) tahun 2021

\section{Aksesibilitas}

Indikator dari aksesibilitas yang terdiri dari kondisi jalur transportasi darat sebelum adanya perusahaan sawit, adanya perusahaan bagaimana kondisi jalur transportasi darat, apakah ada petunjuk jalan menuju kampung tersedia, apakah masih ada masyarakat yang menggunakan jalur transportasi sungai menuju kota, dengan adanya perusahaan jalan dari kampung mudah ditempuh. Aksesbilitas Kampung Punan Malinau skornya adalah 965, skor maksimal indikator dari aksesibilitas adalah 1.100. Dengan menentukan nilai aksesibilitas adalah 87,73\%, dan berdasarkan skala likert tergolong sangat baik.

6. Kesehatan

Indikator dari kesehatan yang terdiri dari apakah anda sering terkena penyakit ispa, flu, dan penyakit kulit, sarana kesehatan sudah tersedia dengan baik, pihak perusahaan selalu membantu masyarakat kampung mengelola lingkungan kesehatan, pertolongan pada pasien tepat waktu, pihak perusahaan selalu membantu pengobatan masyarakat yang diakibatkan dalam kegiatan perusahaan. Kesehatan masyakarat 
Kampung Punan Malinau skornya adalah 1045, skor maksimal adalah 1.100. dengan menentukan nilai kesehatan adalah 96,00\%, dan berdasarkan skala likert tergolong sangat baik. Maka hasil total keseluruhan nilai skor indikator yaitu sebesar 6426.

\section{Pembahasan}

1. Interaksi sosial

Hasil analisis penelitian tentang interaksi sosial masyarakat Kampung Punan Malinau nilainya $=90,65 \%$ dan tergolong sangat baik, karena masih sangat terjalin dengan baik, hal ini didukung dengan berdasarkan jawaban responden rata-rata skor lima (5) dengan kategori sangat baik jawaban responden, adanya gotong royong yang masih sangat rutin dilaksanakan, meringankan sebuah beban pekerjaan, saling menegur dan berbincang dengan masyarakat lainnya, selau menyelesaikan permasalahan masyarakat dengan musyawarah bersama, hubungan baik dengan pihak perusahaan, pihak perusahaan selalu memberikan bantuan terhadap acara keagamaan, toleransi umat beragama terjalin dengan sangat baik walapun dimasyarakat berbeda agama dan suku, tidak pernah terjadi konflik antara masyarakat dan perusahaan. Dengan adanya perusahaan di wilayah Kampung Punan Malinau tentunya ada penduduk baru yang ada disana seperti suku lain.

Walgito (2007) mengemukakan interaksi sosial adalah antara individu satu dengan individu lain, individu satu dapat mempengaruhi individu yang lain atau sebaliknya, sehingga terdapat hubungan yang saling timbal balik. Hubungan tersebut dapat terjadi antara individu dengan individu, individu dengan kelompok atau kelompok dengan kelompok.

Menurut Partowisastro (2003) interaksi sosial ialah relasi sosial yang berfungsi menjalin berbagai jenis relasi sosial yang dinamis, baik relasi itu berbentuk antar individu, kelompok dengan kelompok, atau individu dengan kelompok. Menurut Sarwono dan Meinarno (2009) interaksi sosial adalah hubungan timbal balik yang saling mempengaruhi antara individu dengan individu lain, individu dengan kelompok, dan kelompok dengan kelompok lain.

Menurut Gerungan (2006) secara lebih mendalam menyatakan interaksi sosial adalah proses individu satu dapat menyesuaikan diri secara autoplastis kepada individu yang lain, dimana dipengaruhi diri secara aloplatis dengan individu lain, dimana individu yang lain itulah yang dipengaruhi oleh dirinya yang pertama.

Jadi interaksi sosial adalah hubungan timbal balik yang saling mempengaruhi, mengubah, atau memperbaiki perilaku yang berlangsung antara individu dengan individu, individu dengan kelompok, atau kelompok dengan kelompok.

\section{Pendidikan}

Hasil analisis penelitian tentang pendidikan masyarakat Kampung Punan Malinau nilainya $=94,09 \%$ dan tergolong baik, dikarenakan pendidikan di Kampung Punan Malinau, mengalami perkembangan yang sangat baik yaitu skor (5) berdasarkan jawababan rata-rata responden, ini terbukti dari tingginya minat masyarakat untuk belajar dan melanjutkan pendidikan formal ke tingkat yang lebih tinggi bahkan sampai ke perguruan tinggi ataupun memberikan pendidikan yang baik untuk para anak-anak mereka.

Pada saat ini semua anak-anak usia sekolah karena pendidikan sangat penting, tersedia lembaga pendidikan (sekolah) dengan fasilitas yang lengkap (TK,SD,SMP,SMA/SMK) dan biaya pendidikan masih terjangkau bagi masyarakat. Dengan demikian dalam hal pendidikan di Kampung Punan Malinau kondisinya sangat baik dengan berdasarkan rata-rata jawaban responden.

Pendidikan merupakan tanggung jawab bersama antar keluarga masyarakat dan pemerintah, untuk itu 
perlu ditingkatkan lagi kesadaran masyarakat akan pentingnya pendidikan di Kampung Punan Malinau sampai saat ini cukup baik. Pada saat ini semua anak-anak sekolah dapat bersekolah, hal ini sesuai upaya warga masyarakat dalam penyediaan sarana dan prasarana pendidikan di Kampung Punan Malinau. Pendidikan masyarakat di Kampung Punan Malinau dulunya sangat rendah itu dikarenakan sekolahan tidak ada. Saat ini di Kampung Punan Malinau sudah memiliki fasilitas belajar mengajar mulai dari tingkat TK sampai Sekolah Dasar sedangkan untuk tingkat Sekolah Menengah Pertama dan Sekolah Menengah Atas terdapat di Kecamatan yang setiap harinya harus ditempuh dengan jarak $21 \mathrm{~km}$ dengan menggunakan transportasi pulang pergi yang telah disediakan oleh pihak perusahaan di sekitar wilayah kampung berupa bus sekolah dan truk.

Pendidikan adalah satu hal penting dalam memajukan tingkat kesejahteraan pada umumnya dan tingkat perekonomian, pada khususnya dengan tingkat pendidikan yang tinggi maka akan mendongkrak tingkat kecakapan. Tingkat kecakapan juga akan mendorong tumbuhnya keterampilan kewirausahaan dan pada gilirannya mendorong munculnya lapangan pekerjaan baru, dengan sendirinya akan membantu program pemerintah untuk pembukaan lapangan kerja baru guna mengatasi pengangguran. Pendidikan biasanya akan dapat mempertajam sistematika pikir atau pola pikir individu selain itu mudah menerima informasi yang lebih maju. Pendidikan masyarakat Kampung Punan Malinau sudah ada perubahannya karena banyak masyarakat yang sudah melanjutkan sekolah mereka ke tingkat yang lebih tinggi.

Menurut Mudyahardjo (2012), pendidikan dalam arti makro (luas) adalah proses interaksi antara manusia sebagai individu atau pribadi dan lingkungan alam semesta, lingkungan sosial, masyarakat, sosial ekonomi, sosial politik dan sosial budaya. Pendidikan dalam arti luas juga dapat diartikan hidup segala pengalaman belajar yang berlangsung dalam segala lingkungana dan sepanjang hidup.

\section{Pekerjaan}

Hasil analisis penelitian tentang pekerjaan masyarakat Kampung Punan Malinau nilainya $=74,55 \%$ dan tergolong baik, karena adanya pekerjaan di Kampung Punan Malinau dimana sebelum adanya perusahaan sawit di wilayah kampung rata-rata pekerjaan masyarakat setempat yaitu berkebun, setelah adanya perusahaan sawit masyarakat bekerja di perusahaan tersebut, jabatan masyarakat kampung sebagian besar karyawan biasa adapun yang asisten dan manager hanya beberapa orang saja, bekerja di perusahaan sawit penghasilannya sesuai, sudah memahami bidang pekerjaan dengan baik. sebelum adanya perusahaan masyarakat rata-rata bekerja sebagai pencari rotan dan berternak lalu berubah lagi dengan berkebun kakao, perkebunan kakao ini cukup lumayan lama digeluti oleh masyarakat, namun dengan seiring berjalannya waktu masuklah perusahaan sawit di wilayah Kampung Punan Malinau sampai dengan saat ini, hal ini tentunya merubah pola pikir masyarakat terkait mata pencaharian sehingga masyarakat beralih menanam kelapa sawit. Karena menurut masyarakat penjualan hasil kebun sawit terbilang mudah karena perusahaan sudah membangun pabrik yang jaraknya tidak jauh dari kampung sehingga masyarakat mudah menjangkaunya.

Pekerjaan tetap masyarakat ialah bekerja di perusahaan dengan penghasilan kebun sawit pribadi dan dari perusahaan. Dulunya pekerjaan tidak tetap hanya dengan mencari rotan dan beternak saja dengan penghasilan yang rendah.

Menurut Daniel bali, pekerjaan adalah sebuah aktivitas intelektual yang dipelajari sebelumnya dan menjadi sebuah keahlian yang menjadi 
sebuah kegiatan rutin yang dilakukan, dan profesi penting untuk memiliki keterampilan yang teknis dan moral dalam ruang lingkup masyarakat.

Menurut Westwood \& Peter (2008) mendefinisikan bekerja kedalam konteks Socio-Cultural dan konteks ekonomi politik. Dalam kontek sociocultural, secara prinsip, bekerja bisa berkontribusi terhadap kesejahteraan keluarga. Sedangkan dalam konteks okonomi politik, bekerja lebih sebagai promosi karena merepresentasikan status dan penghasilan yang tinggi.

\section{Pendapatan ekonomi}

Hasil analisis penelitian tentang pendapatan ekonomi masyarakat Kampung Punan Malinau nilainya $=91,00 \%$ dan tergolong sangat baik, dikarenakan rata-rata jawaban responden yang meliputi pendapatan sebulan berkisar empat juta rupiah, jumlah tabungan berkisar lima belas juta rupiah, jenis kendaraan yang dimiliki motor dan mobil, sumber pendapatan lain selain dari perusahaan yaitu memiliki kebun sawit pribadi, masyarakat kampung tidak dipersulit saat melamar kerja diperusahaan sawit.

Pertumbuhan ekonomi masyarakat Kampung Punan Malinau secara umum juga mengalami peningkatan, hal ini dinilai dari bertambahnya jumlah penduduk yang memiliki usaha atau pekerjaan walaupun jenis pekerjaan tersebut pada umumnya belum dapat dipastikan bersumber dari hasil usaha yang dilakukan bisa juga diperoleh dari pinjaman modal usaha dari pemerintah. Sesudah adanya perusahaan sawit masyarakat kampung sangat sejahtera dengan berubahnya pekerjaan, pendapatan. Contohnya seperti rumah dulunya biasa saja sekarang rumah bagus kemudian dulunya memakai perahu ketinting dan sekarang rata-rata sudah memakai mobil. Sedangkan dari segi pendapatan masyarakat sebelum adanya perusahaan hanya dibawah Rp.1.000.000,- akan tetapi setelah adanya perusahaan sawit pendapatan mengalami peningkatan yaitu
Rp.4.000.000,- sampai dengan Rp.5.000.000,- keatas didukung dengan adanya pendapatan pribadi mereka yaitu kebun sawit pribadi bisa mencapai Rp.16.000.000,- keatas perbulannya.

Penduduk Kampung Punan Malinau masih banyak yang memiliki usaha atau mata pencaharian tetap dibidang pertanian dan perkebunan, hal ini dapat diindikasikan bahwa masyarakat Kampung Punan Malinau terbebasnya dalam ilmu pengetahuan dibidang pertanian dan perkebunan kakao, kelapa sawit, lada dan karet oleh karena tidak adanya tenaga ahli yang mendampingi mereka dalam hal ini, bagaimana masyarakat berbuat untuk menjadi petani yang baik dan hasil yang maksimal untuk didapatkan.

Masyarakat untuk mendapatkan ilmu pengetahuan di bidang pertanian dan perkebunan hanyalah dari penyampaian seseorang ke orang lain yaitu sesama petani serta penyaluran pupuk bersubsidi tidak tepat waktu sehingga berpengaruh pada hasil produksi pertanian dan perkebunan, meskipun ada tenaga yang dinamakan PPL di kampung, yang tidak bekerja sebagaimana yang diharapkan pemerintah yang menugaskannya sehingga hal semacam ini menyebabkan belum terlepas dari kemiskinan, sementara potensi cukup tersedia.

Menurut Samuelson dan Nordhaus (2003), kondisi seseorang dapat diukur dengan menggunakan konsep pendapatan yang menunjukan jumlah seluruh uang yang diterima oleh seseorang atau rumah tangga selama jangka waktu tertentu.

Definisi lain dari pendapatan adalah jumlah penghasilan yang diperoleh dari hasil pekerjaan dan biasanya pendapatan seseorang dihitung setiap tahun atau setiap bulan. Dengan demikian pendapatan merupakan gambaran terhadap posisi ekonomi keluarga dalam masyarakat.

\section{Aksesibilitas}


Hasil analisis penelitian tentang aksesibilitas masyarakat Kampung Punan Malinau nilainya $=87,73 \%$ dan tergolong sangat baik, dikarenakan ada perubahan jalur transportasi darat yang dulunya tidak baik sekarang sangat baik dengan adanya perusahaan yang ada di wilayah Kampung Punan Malinau, sebelum adanya perusahaan jalan tidak terawat.

Menurut Magribi

aksesibilitas adalah suatu ukuran kenyamanan atau kemudahan lokasi tata guna lahan dalam berinteraksi satu sama lain, dan mudah atau sulitnya lokasi tersebut dicapai melalui transportasi (Black,1981). Pendapat lain, aksesibilitas adalah ukuran kemudahan yang meliputi waktu, biaya, dan usaha dalam melakukan perpindahan anatar tempat-tempat atau kawasan dari sebuah sistem.

Menurut Suthanaya (2009) aksesibilitas merupakan salah satu bagian dari analisis interaksi kegiatan dengan sistem jaringan transportasi yang bertujuan untuk memahami cara kerja sistem tersebut dan menggunakan hubungan analisis antara komponen sistem untuk meramalkan dampak lalu lintas beberapa tata guna lahan atau kebijakan transportasi yang berbeda. Aksesbilitas sering dikaitkan dengan jarak, waktu tempuh dan biaya perjalanan.

Menurut Miro dan Fidel (2004), tingkat aksesibilitas wilayah bisa ditentukan berdasarkan pada beberapa variabel yaitu ketersediaan jaringan jalan, jumlah alat transportasi, panjang, lebar jalan, dan kualitas jalan. Selain itu yang menentukan tinggi rendahnyaa tingkat akses adalah pola pengaturan tata guna lahan. Keberagaman pola pengaturan fasilitas umum antara satu wilayah dengan wilayah lainnya. Seperti keberagaman pola pengaturan fasilitas umum terjadi akibat berpencarnya lokasi fasilitas umum secara geografis dan berbeda jenis dan intensitas kegiatannya. Kondisi ini membuat penyebaran lahan dalam suatu wilayah menjadi tidak merata (heterogen) dan faktor jarak bukan satu-satunya elemen yang menentukan tinggi rendahnya tingkat aksesbilitas.

\section{Kesehatan}

Hasil analisis penelitian tentang kesehatan masyarakat Kampung Punan Malinau nilainya $=95,00 \%$ dan tergolong sangat baik, karena kesehatan masyarakat secara umum baik, dimana kalaupun terserang penyakit umumnya penyakit musiman seperti influenza, batuk dan pilek.

Kesehatan di Kampung Punan Malinau terdapat 2 sarana kesehatan yang aktif digunakan yaitu satu unit Pustu dan satu unit Posyandu. Sarana penunjang lainnya berupa satu unit ambulance dan tenaga kesehatan bidan dan perawat. Begitupun sarana kesehatan di perusahaan terdapat klinik, ambulance, bidan dan perawat. Untuk pelayanan yang bersifat pertolongan pertama dan pengobatan penyakit-penyakit umum seperti penyakit influenza, batuk, pilek, penyakit kulit, dan lain-lain dapat ditangani dengan baik di fasilitas kesehatan yang ada di kampung. Sedangkan untuk mendapatkan pelayanan kesehatan yang berhubungan dengan penyakit-penyakit berat yang sekiranya tidak bisa di layani di Pustu kampung, masyarakat harus pergi ke Kecamatan dan Kabupaten. Meskipun masih berstatus sebagai Pustu namun tenaga kesehatan cukup tersedia dan selalu ada pada saat dibutuhkan, obat-obatan tersedia cukup.

Pihak perusahaan memberikan bantuan biaya pengobatan kepada masyarakat yang diakibatkan oleh kegiatan perusahaan. Sejauh ini pihak perusahaan pun sangat membantu mengelola lingkungan dengan baik sebagai upaya meminimalisir dampak terhadapat lingkungan. Kondisi tersebut di atas menjadi faktor-faktor yang menjadikan kesehatan masyarakat Kampung pada saat ini kondisinya baik dengan berdasarkan rata-rata skor (4) baik jawaban responden. 
Berdasarkan survei kondisi umum kesehatan masyarakat Kampung Punan Malinau untuk usia bayi, balita dan anak-anak rentan dengan penyakit diare, demam, batuk dan muntaber. Sedangkan untuk usia dewasa banyak yang mengeluhkan penyakit hipertensi, rematik, asma, kolestrol, maag, asam urat dan batuk pilek.

Berdasarkan penjelasan dari tenaga kesehatan Pustu Kampung Punan Malinau bahwa penyakit yang diderita masyarakat sebelum adanya kegiatan perkebunan adalah merupakan batuk, pilek, demam atau ISPA ringan yang mudah diobati dengan tumbuhan yang ada di hutan diantaranya rotan, daun sirsak dan lainnya, setelah adanya perusahaan penyakit sama yang diderita masyarakat yaitu ISPA, batuk, pilek dan demam yang sebenarnya penyakit tersebut relatif sama dengan sebelum adanya perusahaan. Hal ini disebabkan perusahaan mengelola lingkungan dengan baik dan berdasarkan penjelasan dari masyarakat bahwa perusahaan selalu melakukan penyiraman pada saat cuaca panas sehingga tidak terjadi debu pada saat kendaraan lewat. Melakukan pengelolaan air hingga kondisinya baik sebelum dialirkan ke sungai.

Kesehatan merupakan tingkat efisiensi fungsional dari makhluk hidup. Pada manusia, kesehatan merupakan kondisi umum dari pikiran dan tubuh seseorang, yang berarti bebas dari segala gangguan penyakit dan kelainan. Sehingga makna kesehatan sendiri yaiutu sebuah kondisi dimana seseorang mengalami keadaan yang normal dan sesuai dengan apa yang seharusnya. Jadi, kesehatan itu sebenarnya adalah sebuah tolak ukur dari suatu keadaan dimana keadaan tersebut normal atau tidaknya.

Menurut Brook (2017), kesehatan adalah sebuah sumber daya yang dimiliki semua manusia dan bukan merupakan suatu tujuan hidup yang perlu dicapai. Kesehatan tidak terfokus kepada fisik yang bugar tetapi meliputi jiwa yang sehat dimana individu dapat bersikap toleran dan dapat menerima perbedaan.

\section{KESIMPULAN}

Berdasarkan hasil dan pembahasan maka dapat disimpulkan bahwa dari penelitian yang berjudul Kondisi Sosial Ekonomi dan Kesehatan Masyarakat dengan Keberadaan Beberapa Perusahaan Sawit. Dapat disimpulkan bahwa tingkat pendidikan di Kampung Punan Malinau mengalami peningkatan setelah adanya perusahaan sawit, karena pendapatan masyarakat meningkat sehingga bisa menabung untuk pendidikan anak. Dan juga perumahan yang dulunya sebagian masyarakat hanya mempunyai rumah panggung, akan tetapi setelah adanya perusahaan sawit masyarakat mulai memperbaiki rumahnya ke semi permanen. Sedangkan dari segi pendapatan masyarakat sebelum adanya perusahaan hanya dibawah Rp.1.000.000,- akan tetapi setelah adanya perusahaan sawit pendapatan mengalami peningkatan yaitu Rp.4.000.000,- sampai dengan Rp.5.000.000,- keatas didukung dengan adanya pendapatan pribadi mereka yaitu kebun sawit pribadi bisa mencapai Rp.16.000.000,- keatas perbulannya.

Berdasarkan hasil, peneliti memberi saran pada pihak-pihak masyarakat dan perusahaan yaitu hubungan yang terjalin baik antar masyarakat dengan perusahaan hendaknya dipertahankan dan saling memberi dampak positif bagi kedua belah pihak dapat terus ditingkatkan.

\section{DAFT AR PUSTAKA}

Arikunto, Suharsimi. (2010). Prosedur Penelitian Suatu Pendekatan Praktik. Jakarta: Rineka Cipta.

Miro dan Fidel. (2004). Perencanaan Transportasi untuk Mahasiswa, Perencanaan dan Praktisi. Jakarta: Erlangga,

Mudyahardjo, Redja. (2012). Pengantar Pendidikan. Jakarta: PT Raja Grafindo Persada. 
Samuelson dan Nordhaus, (2003). IImu Makroenomi, MeGraw-Hill. Media Global Edukasi

Suthanaya, (2009). Analisis Aksesibilitas Penumpang Angkutan Umum Menuju Pusat Kota Denpasar Di Provinsi Bali. GaneC Swara. Edisi Khusus Vol.3 No.3 Desember 2009.

Sarwono, Sarlito W. \& Eko A. Meinarno. (2009). Psikologi Sosial. Jakarta: Penerbit Salemba Humanika.

Sugiyono. (2014). Metode Penelitian Pendidikan Pendekatan Kuantitatif, Kualitatif dan $R \& D$. Bandung: Alfabeta.

Partowisastro, R. (2003). Perbandingan Konsep Diri Interaksi Sosial Anakanak Remaja WNI Asli dengan Keturunan Tionghoa. Laporan Penelitian. Yogyakarta : Fakultas Psikologi UGM.

Westwood dan Peter S. (2008). What Teachers Need To Know About Reading and Writing Difficulties. Victoria: ACER Press 